\title{
Spatial variability in decapod community structure and recruitment in sub-tidal habitats
}

\author{
Martin Robinson*, Oliver Tully \\ Department of Zoology, Trinity College Dublin, Ireland
}

\begin{abstract}
Sub-tidal populations of decapod crustaceans from 5 distinct benthic habitats were sampled at the end of the main settlement season. Divers, using SCUBA equipment, estimated substrate characteristics and complexity, removed sediment samples, and collected quantitative samples of the resident communities using suction sampling at each of the sites. Adult and young-of-the-year (YOY) components of the decapod assemblages were identified. Univariate and multivariate statistical techniques were used to detect between-site differences in the community structure and community statistics of each component. Although YOY individuals were detected at each of the sites, community structure and statistics for the YOY component varied significantly among sites. Between-site differences in the adult component of the community were also identified. Between-site differences in the YOY assemblages varied from that of the adult component, indicating that post-settlement processes, such as predation and migration, play an important role in shaping the community. Variation in physical complexity and other habitat characteristics appeared to contribute to the significant differences in the YOY and adult assemblages. Due to the close proximity of the sample sites to one another, it seems unlikely that restrictions or spatial and temporal variations in larval supply resulted in the between-site differences observed. Substrate choice at settlement would appear to vary between species, with most species rejecting more marginal areas that offer little shelter to either post-larvae or individuals at later stages of development.
\end{abstract}

KEY WORDS: Decapod · Sub-tidal · Habitat - Settlement $\cdot$ Recruitment $\cdot$ Community

\section{INTRODUCTION}

Cohort strength in decapod crustaceans may be determined early in life history (Robinson \& Tully 1998). Both density-dependent (Iribarne et al. 1994, Pile et al. 1996) and density-independent (Doherty 1994) processes may operate at this stage. If settlement and recruitment into the benthic habitat are under densitydependent constraint and the area of habitat is limiting, then these life history processes could control the stock recruitment relationship (if the population is closed), carrying capacity and production of the population within specific habitat types. Many marine invertebrates release dispersive planktonic propagules as part of their reproductive life cycle. The postlarvae of many species have been shown to exhibit both positive and negative taxis towards various cues within the sur-

•E-mail: robinsom@tcd.ie rounding environment, including presence of algae and seagrass (Forward et al. 1996, Morgan et al. 1996, Welch et al. 1998), habitat complexity (Moksnes et al. 1998, Stevens \& Kittaka 1998) and the presence or absence of conspecifics (Crisp \& Meadows 1962, Jensen 1991) or predators (Boudreau et al. 1993, Welch et al. 1998. Diaz et al. 1999). Late in the larval phase, at the time approaching metamorphosis when discriminatory ability increases (Welch et al. 1998), the selection of a suitable habitat plays an important role in subsequent survival. In more mobile species, settlement often occurs into nursery habitats (Cobb \& Wahle 1994, Pile et al. 1996, Moksnes et al. 1998), with a subsequent habitat shift at a later stage of development. Settlement into less favourable environments, due to factors such as wind-forced hydrodynamic processes (Young et al. 1998) or ocean currents (White et al. 1988, McConnaughey et al. 1992), which can strongly influence larval supply, or simply the absence of preferred habitat at 
metamorphosis (Roughgarden et al. 1988), can lead to a drastic increase in both the rate (Connell \& Jones 1991) and magnitude (Moksnes et al. 1998) of initial mortality. Diving excursions by postlarvae to test the suitability of the benthic substrate, and subsequent rejection and return to the water column, have been documented (Cobb et al. 1983). Although such excursions, and the ability to delay metamorphosis, must significantly increase the possibility of encountering a suitable habitat, postponement is not indefinite, and a final, sub-optimal substrate sometimes remains the only choice.

Some species have been shown to be less selective when settling to the benthos. Tupper \& Boutilier (1997) observed no significant habitat preference between rocky reef, cobble, seagrass and sand substrates in settling cunner Tautogolabrus adsperus (Walbaum). The green shore crab Carcinus maenas (L.) settles in a variety of habitats ranging from complex cobble to filamentous algae (Moksnes 1999). At the other extreme, some smaller sessile species make habitat choices on extremely small scales (Keough \& Downs 1982), which significantly affect subsequent mortality. There is evidence that the level of distinction in habitat selection may be closely related to the reproductive biology of the individual species (Cobb et al. 1997, Palma et al. 1998). Larvae of species that are highly fecund and receive little parental care, such as Cancer spp., tend to be less selective at settlement relative to those of less fecund species such as clawed lobsters. Whatever the scale of niche selection, post-settlement mortality is often reduced in more complex habitats (Connell \& Jones 1991, Pile et al. 1996, Tupper \& Boutilier 1997) which afford organisms more shelter. However, recent work by Steele (1999) suggests factors other than mortality, such as increased abundance of prey species in complex habitat, may also influence post-settlement abundance. Mortality and displacement (Iribarne et al. 1994) of early life history stages are often under density-dependent control. Gosselin \& Qian (1997) list numerous studies where population abundance, distribution and community structure are controlled/influenced by juvenile mortality of marine invertebrates. There is evidence that growth rate can also be promoted in certain species when habitat complexity is increased (Connell \& Jones 1991, Perkins-Visser et al. 1996). Complex habitats are generally accepted as supporting both higher densities and diversities of species.

Recently there has been increasing interest in the effects that larval supply, larval choice, substrate selection, and density-dependent mortality and displacement have on the postlarvae-settler-recruit relationships of decapods (Incze \& Wahle 1991, Incze et al. 1997). Although these models may become valuable tools in the prediction of benthic recruitment, the relationship may be habitat-specific, complicating inter- pretation of recruit relationship data. Recent work presented by Hughes et al. (1999) highlighted the need for consideration of spatial scales when examining variation in recruitment and adult distributions. Risk (1997) suggested that the ability of larvae to choose favourable places to settle, and to persist there, may cause patterns of recruitment to differ from those of the larval supply. Larval supply dynamics, larval choice in substrate selection, and post-settlement processes together determine the resultant adult community structure. In this paper we compare spatial variability in the community structure of settlers and adults in a number of discrete shallow sublittoral habitats. The results give an insight into the relative importance of larval supply, larval choice and post-settlement processes in determining the adult community structure.

\section{MATERIAL AND METHODS}

Samples were collected at 5 sites within a $0.5 \mathrm{~nm}^{2}$ area in the Saltees Sound, County Wexford, Ireland. Sampling was conducted during daylight hours on 22 September 1998. This date was identified from the previous year as representing the approximate end of the settlement season for most species. The sediment structure and conditions at each site were known prior to sampling based on information obtained during SCUBA and remote video surveys. Sites were selected to be representative of a number of habitats typical of the area encompassed within the bay. The area consists of bands of varying substrate orientated parallel to the shoreline, ranging from mud to solid bedrock. The area within the Saltees Sound contains patches of more solid substrate types.

Divers using SCUBA equipment randomly positioned $0.5 \times 0.5 \mathrm{~m}$ quadrats. The area contained within each quadrat was sampled in situ using a diver-operated suction sampler. Air supply to the sampler was provided via a spare diving cylinder carried by the operator. In situ sampling permitted collection from sheltered lower surfaces and crevices of large rocks and boulders that support high densities of juvenile decapods. Sampling methodologies employing grab samples or dredging fail to adequately sample such habitats. Four replicate samples were taken at each site. Although this represents a low number of samples, a large-scale temporal study in the previous year with greater replication (10 to 15 samples $\mathrm{d}^{-1}$ ) had shown that community structure was not significantly different between samples taken within a habitat on the same day (authors' unpubl. data). All fauna was collected in rigid $1 \mathrm{~mm}$ mesh bags. Substrate samples were taken by manually placing the contents of 1 quadrat from each site into lidded buckets. The same 
divers conducted surveys at each site, ensuring the same methodology was employed. The proportion of each area covered by solid bedrock was estimated, whether exposed on the surface or underlying loose rock cover. The proportion of the area covered by loose boulders larger than $150 \mathrm{~mm}$ in diameter was estimated. Algal cover, mainly Laminaria spp. when present, was estimated at each of the sites. Finally, the percentage coverage of loose rock was estimated, defined as the area covered by stones larger than $50 \mathrm{~mm}$ in diameter, which obscured the finer underlying material. The proportion of area covered by loose rock and cobble, and hence the interstitial space afforded as shelter (Wahle 1992), was considered a good indication of the physical complexity of the habitat sampled.

In the laboratory, samples were sieved, while submerged in seawater, through progressively smaller mesh sizes down to $1.0 \mathrm{~mm}$. Individual decapods were fixed in 5\% formalin, containing 5\% glycerol to maintain flexibility. Maximum carapace widths of large crabs (>3.0 mm) were recorded to $0.1 \mathrm{~mm}$ using digital callipers. Individuals smaller than $3.0 \mathrm{~mm}$ were sized to the nearest $0.1 \mathrm{~mm}$, using a binocular microscope micrometer, Carapace length was recorded for Galatheidae, uropod length and eye width for Caridea and shield length for Paguridae. It was necessary to record different body dimensions so comparison to samples taken in previous years that used this protocol could be made. The total wet weight of individuals was recorded using a Sartorius 3 point balance. Sediment samples were sieved through progressively smaller meshes, to a size of $<710 \mu \mathrm{m}$. The substrate retained within each sieve was oven-dried and weighed.

The number of young-of-the-year (YOY) specimens within each sample was estimated by construction of length-frequency histograms. When the number of individuals sampled was sufficient, gaps appeared in the distributions, distinguishing newly settled individuals from cohorts established in previous years. The number of individuals required to identify the YOY cohort varied with species, but in general only 1 or 2 individuals were required. Growth data for YOY individuals of numerous species were collected during surveys throughout the previous settlement season of 1997. This time series of information was also used as a guide when identifying YOY individuals in the 1998 data. The component of the population referred to as adult in this study also includes immature individuals, and as such should be taken to refer to individuals settled in previous years.

The total number of species and individuals within each sample was used to calculate diversity (Shannon), evenness (Pielou), and dominance (Simpson) indices $\left(\log _{e}\right)$ for the YOY and adult components of the community. Between-site differences in each of these para- meters were examined using ANOVA. Although the number of samples taken from each site was small, variances were considered sufficiently homogenous (Cochran's test) to permit use of parametric statistics. Post hoc tests revealed sources of significant betweensite differences. Analysis of abundance data was conducted on adult and YOY components separately after In transformation. Due to the dominance of Pisidia longicornis (L.), between-site differences in abundance were also examined after removal of the species from the data matrix. Biomass was not treated in this way as the periodic occurrence of single large individuals, of species such as Cancer pagurus L., strongly affected the suitability of the analyses due to high within-group variance.

Multidimensional scaling ordination (MDS) (Kruskal \& Wish 1978) was carried out on the adult and YOY components of the population separately using the computer package Primer $^{\circ}$ in order to examine between-site differences in community structure in more detail. Species that did not represent more than $4 \%$ of the total abundance in any 1 sample were removed from the data matrix. Data was double-root transformed to reduce the influence of more dominant species. The significance of differences in between-site Euclidean dissimilarities was tested using the ANOSIM routine (Clarke \& Warwick 1994). Bray-Curtis similarities, which are more regularly associated with the analysis of biological data, were not used, as joint absences of species were considered important in such variable sites where lack of larval supply was probably not a cause for absence. The program ANOSIM computes the average rank dissimilarity between withinsite samples and subtracts this from the average dissimilarity between samples from different sites (Warwick et al. 1990). Significant variation between sites is identified when samples within sites are more similar than samples from other sites.

Within-site differences between YOY and adult community composition were examined using ANOSIM after presence/absence transformation. This severe transformation removed the influence of the large differences between YOY and adult abundances, allowing a direct comparison of newly settled species with those already established in the area. The total proportion of individuals at each site representing the YOY component within the community was examined using ANOVA after arcsine transformation. Post hoc tests revealed sources of any significant between-site differences.

Environmental data in the form of diver estimates of overall sediment structure were compared to mean number of species and individuals by site, and to the derived diversity indices mentioned above, using Pearson's correlation. 
Table 1. Sediment grain size composition expressed as proportion of sample dry weight (g) represented by each size component and diver estimates of substrate characteristics ("). Substrate characteristics do not equal $100 \%$ as each is an independent estimation of coverage

\begin{tabular}{|lrrrrr|}
\hline & Site 1 & Site 2 & Site 3 & Site 4 & Site 5 \\
\hline \% large stone (50 to 149 mm diameter) & 72.9 & 78.7 & 0.0 & 72.8 & 76.1 \\
\% small stone (5 to 49 mm diameter) & 12.3 & 19.2 & 7.7 & 12.0 & 22.9 \\
\% course sand (2 to 5 mm diameter) & 1.5 & 0.4 & 2.1 & 1.2 & 0.4 \\
\% fine sand (<2 mm diameter) & 13.3 & 1.7 & 90.2 & 14.0 & 0.6 \\
Total of above (\%) & 100 & 100 & 100 & 100 & 100 \\
\% area covered by solid bedrock & 20 & 60 & 0 & 20 & 100 \\
\% area covered by $>$ 150 mm diameter & 15 & 15 & 0 & 15 & 5 \\
\% algal coverage & 10 & 75 & 0 & 75 & 35 \\
\% area covered by loose rock & 75 & 95 & 0 & 75 & 25 \\
Low water chast depth (m) & 12 & 9 & 8 & 8 & 6 \\
\hline \multicolumn{1}{l}{ * } & & & &
\end{tabular}

ment (Table 1). There was an equally low proportion of fine sediment at Site 5, which was entirely covered by solid bedrock. Only patches covered by loose stone and cobble, which covered approximately $25 \%$ of this solid ridge, were sampled. Areas consisting of only bedrock were not sampled as they offered little shelter, only the occasional large Cancer pagurus was encountered during inspection. The substrate at Site 3 consisted almost entirely of fine sand $(90 \%)$. A few small stones (5 to $49 \mathrm{~mm}$ ) were scattered around the site, but the availability of intersti-

\section{RESULTS}

The proportion of the total weight of sediment samples represented by each size component was calculated and combined with diver estimates of site characteristics (Table 1). The substrate at Site 1, which con-sisted of a stone and boulder surface layer overlaying a layer of finer sediment made up of sand and shell debris, was almost identical to Site 4 in composition (Table 1). The only noticeable differences between the 2 sites were the proportion of algal cover, which was more extensive at Site 4 (10 vs 75\%), and the additional depth at Site $1(12$ vs $8 \mathrm{~m})$. Site 2 consisted of a substrate similar to that of Sites 1 and 4 , but with a higher coverage of overlaying stone and boulder (90 to $100 \%)$, a larger amount of underlying bedrock $(60 \%)$, and a lower proportion of finer sedi- tial space of a size suitable to afford shelter to decapods was negligible.

A total of 4333 individuals from 17 decapod species was collected during the study. There was a large variation in the number of YOY individuals between sites (Table 2). The highest mean density of YOY individuals $\left(2220 \mathrm{~m}^{-2}\right)$ was at Site 2 , with lowest density $\left(36 \mathrm{~m}^{-2}\right)$ recorded at Site 3 (Table 3). Low diversity in the YOY component of the population at Sites 1,2 and 4 coincided with high dominance and low evenness. The mean density, number of species, and each of the diversity indices calculated for YOY individuals varied significantly $(\mathrm{p}<0.05$ ) between sites (Table 3 ). The sources of between-site differences were identified using Scheffé's post hoc test (Table 4). The mean proportion of the population represented by YOY individuals was significantly $(\mathrm{p}<0.05$ ) higher in Sites 1 and 3

Table 2. Abundance of species sampled from 5 distinct sub-tidal habitats (1-5), with 4 replicates taken from each site (A-D). $y$ : Young-of-the-year component; a: individuals settled in previous years

\begin{tabular}{|c|c|c|c|c|c|c|c|c|c|c|c|c|c|c|c|c|}
\hline & $1 \mathrm{Ay}$ & $1 \mathrm{Aa}$ & $1 \mathrm{By}$ & $1 \mathrm{Ba}$ & $1 \mathrm{Cy}$ & $1 \mathrm{Ca}$ & $1 \mathrm{Dy}$ & $1 \mathrm{Da}$ & $2 \mathrm{Ay}$ & $2 \mathrm{Aa}$ & $2 \mathrm{By}$ & $2 \mathrm{Ba}$ & $2 \mathrm{C}_{Y}$ & $2 \mathrm{Ca}$ & $2 \mathrm{Dy}$ & $2 \mathrm{Da}$ \\
\hline Anapagurus hyndmanni & 3 & 0 & 3 & 0 & 0 & 0 & 2 & 0 & 0 & 2 & 3 & 1 & 1 & 1 & 13 & 1 \\
\hline Athanas nitescens & 0 & 0 & 0 & 0 & 0 & 0 & 0 & 0 & 0 & 0 & 0 & 0 & 0 & 0 & 0 & 0 \\
\hline Cancer pagurus & 0 & 0 & 1 & 0 & 1 & 0 & 2 & 0 & 3 & 0 & 5 & 1 & 3 & 2 & 1 & 0 \\
\hline Galathea intermedia & 0 & 0 & 0 & 0 & 0 & 0 & 0 & 0 & 0 & 0 & 0 & 0 & 0 & 0 & 0 & 0 \\
\hline Galathea squamifera & 0 & 0 & 0 & 0 & 0 & 0 & 0 & 0 & 1 & 1 & 0 & 0 & 0 & 0 & 0 & 0 \\
\hline Hippolyte variens & 0 & 0 & 0 & 0 & 1 & 2 & 0 & 0 & 2 & 2 & 3 & 2 & 0 & 0 & 0 & 1 \\
\hline Inachus phalangium & $\mathrm{u}$ & 0 & 0 & 0 & 0 & 0 & 0 & 0 & 0 & 0 & 1 & 0 & 0 & 0 & 0 & 0 \\
\hline Necora puber & 1 & 0 & 0 & 0 & 1 & 0 & 4 & 0 & 1 & 2 & 0 & 4 & 0 & 0 & 4 & 3 \\
\hline Pagurus bernhardus & 0 & 0 & 0 & 0 & 0 & 1 & 0 & 0 & 0 & 1 & 0 & 0 & 0 & 0 & 0 & 0 \\
\hline Pilumnus hirtellus & 0 & 0 & 0 & 0 & 0 & 0 & 0 & 0 & 1 & 2 & 1 & 1 & 2 & 1 & 0 & 0 \\
\hline Pirimela denticulata & 2 & 1 & 1 & 0 & 0 & 0 & 1 & 0 & 1 & 0 & 0 & 0 & 0 & 0 & 2 & 3 \\
\hline Pisidia longicornis & 112 & 0 & 127 & 6 & 103 & 8 & 163 & 6 & 533 & 75 & 490 & 48 & 479 & 67 & 644 & 37 \\
\hline Pontophilus fasciatus & 0 & 1 & 0 & 0 & 0 & 1 & 0 & 0 & 0 & 0 & 0 & 0 & 0 & 0 & 0 & 2 \\
\hline Porcellana platycheales & 0 & 0 & 0 & 0 & 0 & 0 & 0 & 0 & 0 & 0 & 1 & 0 & 0 & 0 & 0 & 0 \\
\hline Processa canaliculata & 0 & 0 & 0 & 0 & 0 & 0 & 0 & 0 & 0 & 0 & 0 & 0 & 0 & 0 & 0 & 2 \\
\hline Thoralus cranchii & 1 & 2 & 2 & 2 & 0 & 2 & 1 & 2 & 3 & 5 & 8 & 10 & 4 & 5 & 0 & 0 \\
\hline Xantho pilipes & 0 & 1 & 3 & 0 & 1 & 0 & 0 & 0 & 0 & 2 & 1 & 3 & 3 & 3 & 5 & 2 \\
\hline
\end{tabular}


Table 3. Mean $( \pm \mathrm{SD}$ ) values for community statistics for each site and results of ANOVA. Percentage young-of-the-year (YOY) arcsine transformed prior to ANOVA. Abundances ln transformed. Values missing from adult indices involving Site 3 due to occurrence of a single individual in 2 samples

\begin{tabular}{|c|c|c|c|c|c|c|c|}
\hline Source & Site 1 & Site 2 & Site 3 & Site 4 & Site 5 & $\mathrm{df}$ & $\mathrm{p}$ \\
\hline$\%$ proportion YOY & $94(3)$ & $88(4)$ & $93(9)$ & $81(4)$ & $69(5)$ & 19 & $<0.001$ \\
\hline Adult species & $3(2)$ & $8(1)$ & $2(1)$ & $8(2)$ & $5(1)$ & 19 & $<0.001$ \\
\hline YOY species & $6(1)$ & $7(2)$ & $3(1)$ & $8(1)$ & $5(1)$ & 19 & $<0.001$ \\
\hline Adult individuals $0.25 \mathrm{~m}^{-2}$ & $9(4)$ & $73(17)$ & $2(1)$ & $44(8)$ & $22(8)$ & 19 & $<0.001$ \\
\hline YOY individuals $0.25 \mathrm{~m}^{-2}$ & $134(29)$ & $555(79)$ & $9(6)$ & $189(67)$ & $47(13)$ & 19 & $<0.001$ \\
\hline Adult Shannon diversity $\left(H^{\prime}\right)$ & $0.93(0.42)$ & $0.93(0.23)$ & - & $1.44(0.33)$ & $1.30(0.24)$ & 19 & 0.09 \\
\hline YOY Shannon diversity $\left(H^{\prime}\right)$ & $0.30(0.07)$ & $0.20(0.05)$ & $0.64(0.22)$ & $0.45(0.18)$ & $0.71(0.10)$ & 19 & $<0.001$ \\
\hline Adult Pielou evenness $(J)$ & $0.84(0.08)$ & $0.45(0.10)$ & - & $0.69(0.15)$ & $0.81(0.07)$ & 19 & $<0.001$ \\
\hline YOY Pielou evenness $(J)$ & $0.17\{0.03\}$ & $0.10(0.02)$ & $0.75(0.07)$ & $0.22(0.08)$ & $0.46(0.07)$ & 19 & $<0.001$ \\
\hline Adult Simpson dominance $(D)$ & $0.48(0.18)$ & $0.61(0.11)$ & - & $0.36(0.15)$ & $0.33(0.07)$ & 19 & 0.04 \\
\hline YOY Simpson dominance $(D)$ & $0.89(0.03)$ & $0.94(0.02)$ & $0.61(0.09)$ & $0.83(0.08)$ & $0.67(0.05)$ & 19 & $<0.001$ \\
\hline
\end{tabular}

than in Site 5 (Table 4). Although the mean proportion of settlers was also higher at Sites 1 and 3 than 2 and 4 , the difference was not statistically significant at the $5 \%$ level. Analyses of the abundance of YOY individuals showed significant between-site differences $(\mathrm{p}<$ $0.01)$, before and after removal pisidia longicornis (Table 3). Post hoc tests of YOY abundance (Table 4), including $P$. longicornis, revealed differences between all sites except Sites 1 and 4 . When $P$. Iongicornis was removed, Site 3 differed from Sites 4 and 2 at the $5 \%$ level, and from Sites 1 and 5 at the $10 \%$ level. No other between-site differences in YOY abundance were observed.

The greatest mean number of adult species (8) was encountered at Sites 2 and 4 , while the highest overall mean density of adult individuals $\left(292 \mathrm{~m}^{-2}\right)$ was at Site 2 . The lowest overall mean number of adult spe- cies (2) and individuals $\left(8 \mathrm{~m}^{-2}\right)$ occurred at Site 3 (Table 3). Adult diversity, evenness and dominance were not calculated for Site 3 as 2 of the samples contained only 1 individual. This strongly influenced the values derived using these methods, resulting in a significant reduction in the homogeneity of variances. Although Site 3 was excluded from subsequent ANOVA of adult indices, raw data (Table 2) would suggest that the adult community at this site differed from all other sites. The 4 remaining sites displayed between-site variation in evenness and dominance, but not in diversity (Table 3). Analyses of the abundance of adult individuals also showed significant between-site differences $(\mathrm{p}<0.01)$, before and after removal Pisidia longicornis (Table 3). Tests on adult (including $P$. longicornis) abundance data revealed similarities between Site 4 and Sites 5 and 2, and

$3 \mathrm{Ay} 3 \mathrm{Aa} 3 \mathrm{By} 3 \mathrm{Ba} 3 \mathrm{Cy} 3 \mathrm{Ca} 3 \mathrm{Dy} 3 \mathrm{Da}$ 4Ay 4Aa 4By 4Ba 4Cy 4Ca 4Dy 4Da 5Ay 5Aa 5By 5Ba 5Cy 5Ca 5Dy 5Da

\begin{tabular}{|c|c|c|c|c|c|c|c|c|c|c|c|c|c|c|c|c|c|c|c|c|c|c|c|}
\hline 0 & 1 & 0 & 0 & 0 & 0 & 0 & 0 & 4 & 2 & 4 & 0 & 0 & 0 & 3 & 0 & 2 & 0 & 0 & 0 & 0 & 1 & 0 & 0 \\
\hline 0 & 0 & 0 & 0 & 0 & 0 & 0 & 0 & 0 & 0 & 0 & 0 & 2 & 1 & 0 & 0 & 0 & 0 & 0 & 0 & 0 & 0 & 0 & 0 \\
\hline 0 & 0 & 0 & 0 & 0 & 0 & 0 & 0 & 1 & 1 & 5 & 0 & 0 & 3 & 1 & 1 & 0 & 2 & 1 & 0 & 4 & 3 & 0 & 0 \\
\hline 0 & 0 & 0 & 0 & 0 & 0 & 0 & 0 & 0 & 1. & 0 & 0 & 0 & 0 & 0 & 0 & 0 & 0 & 0 & 0 & 0 & 0 & 0 & 0 \\
\hline 0 & 0 & 0 & 0 & 0 & 0 & 0 & 0 & 1 & 0 & 1 & 0 & 1 & 2 & 2 & 0 & 0 & 0 & 0 & 0 & 0 & 0 & 0 & 0 \\
\hline 0 & 0 & 0 & 0 & 0 & 0 & 0 & 0 & 1 & 5 & 2 & 4 & 1 & 4 & 3 & 4 & 0 & 1 & 1 & 6 & 0 & 0 & 0 & 2 \\
\hline 0 & 0 & 0 & 0 & 0 & 0 & 0 & 0 & 0 & 0 & 0 & 1 & 0 & 0 & 0 & 0 & 0 & 0 & 2 & 0 & 0 & 0 & 0 & 0 \\
\hline 2 & 0 & 1 & 1 & 0 & 0 & 1 & 0 & 4 & 5 & 0 & 1 & 2 & 0 & 1 & 1 & 0 & 0 & 0 & 1 & 1 & 0 & 4 & 0 \\
\hline 0 & 0 & 0 & 0 & 0 & 0 & 0 & 0 & 0 & 3 & 0 & 1 & 0 & 0 & 0 & 1 & 0 & 1 & 0 & 0 & 0 & 0 & 0 & 0 \\
\hline 0 & 0 & 0 & 0 & 0 & 0 & 0 & 0 & 0 & 0 & 1 & 0 & 2 & 0 & 0 & 0 & 0 & 0 & 1 & 1 & 0 & 0 & 3 & 1 \\
\hline 0 & 0 & 1 & 1 & 1 & 0 & 0 & 0 & 1 & 1 & 0 & 1 & 0 & 0 & 0 & 0 & 1 & 2 & 0 & 0 & 2 & 1 & 0 & 0 \\
\hline 9 & 0 & 11 & 0 & 3 & 0 & 3 & 0 & 138 & 13 & 226 & 26 & 95 & 13 & 238 & 39 & 24 & 2 & 42 & 9 & 37 & 4 & 47 & 9 \\
\hline 0 & 0 & 0 & 1 & 0 & 1 & 0 & 1 & 0 & 1 & 0 & 1 & 0 & 0 & 0 & 2 & 0 & 0 & 0 & 0 & 0 & 0 & 0 & 0 \\
\hline 0 & 0 & 0 & 0 & 0 & 0 & 0 & 0 & 0 & 0 & 0 & 1 & 1 & 0 & 0 & 0 & 0 & 0 & 0 & 0 & 0 & 0 & 0 & 0 \\
\hline 0 & 0 & 0 & 0 & 0 & 0 & 0 & 0 & 0 & 0 & 0 & 0 & 0 & 0 & 0 & 0 & 0 & 0 & 0 & 0 & 0 & 0 & 0 & 0 \\
\hline 0 & 0 & 4 & 1 & 0 & 0 & 0 & 0 & 4 & 13 & 2 & 7 & 7 & 12 & 1 & 5 & 1 & 5 & 4 & 16 & 3 & 11 & 6 & 10 \\
\hline 0 & 1 & 0 & 0 & 0 & 0 & 0 & 0 & 1 & 0 & 0 & 0 & 0 & 0 & 0 & 1 & 0 & 0 & 0 & 0 & 0 & 0 & 0 & 0 \\
\hline
\end{tabular}


Table 4. Scheffé's post hoc test result for between-site differences in community statistics. Proportion young-of-the-year (YOY) arcsine transformed. Total, YOY and adult individuals In transformed. "Significant between-site differences at $5 \%$ level. Values missing from adult indices involving Site 3 due to occurrence of a single individual in 2 samples. Species (sp.), individuals (ind.), diversity (div.), evenness (even.) and dominance (dom.)

\begin{tabular}{|c|c|c|c|c|c|c|c|c|c|c|c|c|c|}
\hline Sites & $\begin{array}{l}\text { Prop. } \\
\text { YOY } \\
\text { p }\end{array}$ & $\begin{array}{l}\text { YOY } \\
\text { sp. } \\
\text { p }\end{array}$ & $\begin{array}{l}\text { Ad. } \\
\text { sp. } \\
\text { p }\end{array}$ & $\begin{array}{l}\text { YOY } \\
\text { ind. } \\
p\end{array}$ & $\begin{array}{l}\text { Ad. } \\
\text { ind } \\
p\end{array}$ & $\begin{array}{c}\text { Pisidia longifo } \\
\text { YOY ind. } \\
p\end{array}$ & $\begin{array}{l}\text { Ad. ind. } \\
\text { p }\end{array}$ & $\begin{array}{l}\text { YOY } \\
\text { div. } \\
p\end{array}$ & $\begin{array}{l}\text { Ad. } \\
\text { div. } \\
p\end{array}$ & $\begin{array}{l}\text { YOY } \\
\text { even. } \\
\text { p }\end{array}$ & $\begin{array}{l}\text { Ad. } \\
\text { even. } \\
\text { p }\end{array}$ & $\begin{array}{l}\text { YOY } \\
\text { dom. } \\
\text { p }\end{array}$ & $\begin{array}{l}\text { Ad. } \\
\text { dom } \\
p\end{array}$ \\
\hline $1 \& 2$ & 0.76 & 0.28 & $<0.01^{\circ}$ & $<0.01^{\circ}$ & $<0.01^{\circ}$ & 0.74 & $<0.01^{\circ}$ & 0.90 & $>0.99$ & 0.56 & $<0.01^{\circ}$ & 0.89 & 0.59 \\
\hline $1 \& 3$ & 0.99 & $0.02^{\circ}$ & 0.80 & $<0.01^{\circ}$ & $<0.01^{\circ}$ & 0.08 & 0.45 & 0.05 & - & $<0.01^{\circ}$ & - & $<0.01^{\circ}$ & - \\
\hline $1 \& 4$ & 0.19 & 0.10 & $<0.01^{\circ}$ & 0.90 & $<0.01^{\circ}$ & 0.88 & $<0.01^{\circ}$ & 0.68 & 0.21 & 0.90 & 0.27 & 0.76 & 0.65 \\
\hline $1 \& 5$ & $0.01^{\circ}$ & 0.90 & 0.54 & $0.04^{\circ}$ & 0.07 & $>0.99$ & $<0.01^{\circ}$ & $0.02^{\circ}$ & 0.46 & $<0.01^{\circ}$ & 0.97 & $<0.01^{\circ}$ & 0.51 \\
\hline $2 \& 3$ & 0.51 & $<0.01^{\circ}$ & $<0.01^{\circ}$ & $<0.01^{\circ}$ & $<0.01^{\circ}$ & $<0.01^{\circ}$ & $<0.01^{\circ}$ & $<0.01^{\circ}$ & - & $<0.01^{\circ}$ & - & $<0.01^{\circ}$ & - \\
\hline $2 \& 4$ & 0.80 & 0.98 & 0.99 & $0.03^{\circ}$ & 0.57 & $>0.99$ & 0.95 & 0.22 & 0.21 & 0.16 & 0.05 & 0.27 & 0.11 \\
\hline $2 \& 5$ & 0.13 & 0.06 & 0.15 & $<0.01^{\circ}$ & $0.01^{\circ}$ & 0.79 & $>0.99$ & $<0.01^{\circ}$ & 0.46 & $<0.01^{\circ}$ & $<0.01^{\circ}$ & $<0.01^{\circ}$ & 0.08 \\
\hline $3 \& 4$ & 0.09 & $<0.01^{\circ}$ & $<0.01^{\circ}$ & $<0.01^{\circ}$ & $<0.01^{\circ}$ & $0.01^{\circ}$ & $<0.01^{\circ}$ & 0.47 & - & $<0.01^{\circ}$ & - & $<0.01^{\circ}$ & - \\
\hline $3 \& 5$ & $<0.01^{\circ}$ & 0.10 & 0.10 & $<0.01^{\circ}$ & $<0.01^{\circ}$ & 0.07 & $<0.01^{\circ}$ & 0.98 & - & $<0.01^{\circ}$ & - & 0.70 & - \\
\hline $4 \& 5$ & 0.61 & $0.02^{\circ}$ & 0.06 & $<0.01^{\circ}$ & 0.20 & 0.92 & 0.93 & 0.20 & 0.94 & $<0.01^{\bullet}$ & 0.49 & $0.04^{\circ}$ & $>0.99$ \\
\hline
\end{tabular}

between Sites 5 and 1. Removal of $P$. longicornis led to a similar result but with the addition of no differences between Sites 1 and 3 (Table 4).

Between-site differences in adult community structure were not immediately evident after MDS ordination (Fig. 1). There was some degree of mixing of samples from different sites, with a trend of increasing abundance from left to right in the ordination. Subsequent ANOSIM analysis revealed underlying significant $(p<0.05$ ) between-site differences (Table 5). Differences in community structure were identified at the $6 \%$ level between all sites with the exception of Sites 1 and 3, Sites 1 and 5, and between Sites 4 and 5. Identical analysis of YOY community structure revealed differences between all sites with the exception of Sites 2 and 4 at the $6 \%$ level (Table 5). Clustering of site samples was slightly clearer than that of the adult ordination, especially within Site 3 (Fig. 2). Again, overall abundance of YOY individuals appeared to increase

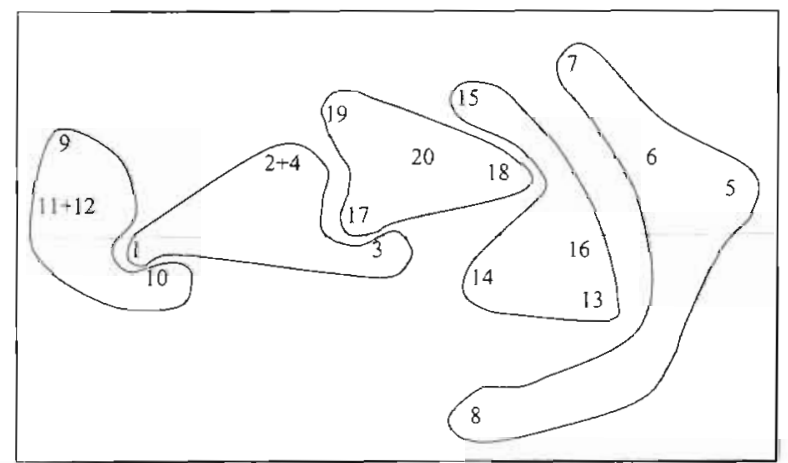

Fig. 1. Multidimensional scaling ordination of adult decapod community abundance recorded in 5 distinct sub-tidal habitats with varying degrees of physical complexity. Grouping by dotted lines indicates replicate samples from each habitat from left to right on the ordination plot. Analysis of presence/absence identified significant differences $(p<0.05)$ between the species found within the YOY and adult components of the community at Sites 1 and 3 . The community composition of YOY and adult individuals was not significantly different at the other 3 sites.

A number of the estimated site characteristics correlated well to the community statistics (Table 6). The strongest correlation, $\mathrm{r}_{\mathrm{p}}=0.991$, occurred between the extent of algal coverage and number of adult species. Density of adult individuals also correlated positively $\left(r_{p}=0.926\right)$ to algal coverage. Although the density and number of species in the adult and YOY components displayed a positive relationship with rock coverage, the correlation was not quite significant at the $5 \%$ level. Diversity and evenness of YOY individuals showed significant negative correlation (-0.928 and

Table 5. Results of ANOSIM for between-site similarities in whole community and young-of-the-year (YOY) component. - Significant between-site difference at $5 \%$ level

\begin{tabular}{|ccccc|}
\hline Sites & \multicolumn{2}{c}{$\begin{array}{c}\text { Adult component } \\
\text { Statistic } \\
\end{array}$} & $\begin{array}{c}\text { Significance } \\
(\mathrm{R})\end{array}$ & \multicolumn{2}{c|}{$\begin{array}{c}\text { YoY component } \\
(\%)\end{array}$} & $\begin{array}{c}\text { Stistic } \\
(\mathrm{R})\end{array}$ & $\begin{array}{c}\text { Significance } \\
(\%)\end{array}$ \\
\hline $1 \& 2$ & 0.72 & $2.9^{\circ}$ & 0.47 & 5.7 \\
$1 \& 3$ & 0.46 & 8.6 & 0.9 & $2.9^{\circ}$ \\
$1 \& 4$ & 0.56 & 5.7 & 0.52 & 5.7 \\
$1 \& 5$ & 0.06 & 28.6 & 0.35 & $5.7^{\circ}$ \\
$2 \& 3$ & 1.00 & $2.9^{\circ}$ & 1.00 & $2.9^{\circ}$ \\
$2 \& 4$ & 0.42 & 5.7 & 0.25 & $11.4^{\circ}$ \\
$2 \& 5$ & 0.56 & $2.9^{\circ}$ & 0.89 & $2.9^{\circ}$ \\
$3 \& 4$ & 0.99 & $2.9^{\circ}$ & 0.98 & $2.9^{\circ}$ \\
$3 \& 5$ & 0.98 & $2.9^{\circ}$ & 0.50 & 5.7 \\
$4 \& 5$ & 0.27 & 20.0 & 0.67 & $2.9^{\circ}$ \\
Global R & 0.62 & $<0.01$ & 0.64 & $<0.01$ \\
\hline
\end{tabular}


Table 6. Pearson's correlation $\left(r_{p}\right)$ between the community statistics and estimated substrate characteristics arcsine transformed. Critical value $\mathrm{rp}$ for $3 \mathrm{df}=0.878$. Species (sp.), individuals (ind.), diversity (div.), evenness (even.) and dominance (dom.) for YOY only

\begin{tabular}{|c|c|c|c|c|c|c|c|}
\hline & Ad. sp. & YOY sp. & Ad. ind. & YOY ind. & Shan. div. & Piel. even. & Simp. dom. \\
\hline$\%$ Area covered by solid bedrock & 0.228 & -0.002 & 0.186 & 0.011 & 0.351 & -0.035 & -0.165 \\
\hline$\%$ Area covered by $>150 \mathrm{~mm}$ diameter & 0.189 & 0.083 & 0.056 & -0.149 & 0.390 & -0.083 & -0.154 \\
\hline$\%$ Algal coverage & 0.991 & 0.794 & 0.926 & 0.713 & -0.377 & -0.579 & 0.505 \\
\hline$\%$ Area covered by loose rock & 0.706 & 0.859 & 0.785 & 0.869 & -0.928 & -0.960 & 0.984 \\
\hline Low water chart depth (m) & -0.230 & 0.214 & -0.099 & 0.229 & -0.736 & -0.497 & 0.639 \\
\hline
\end{tabular}

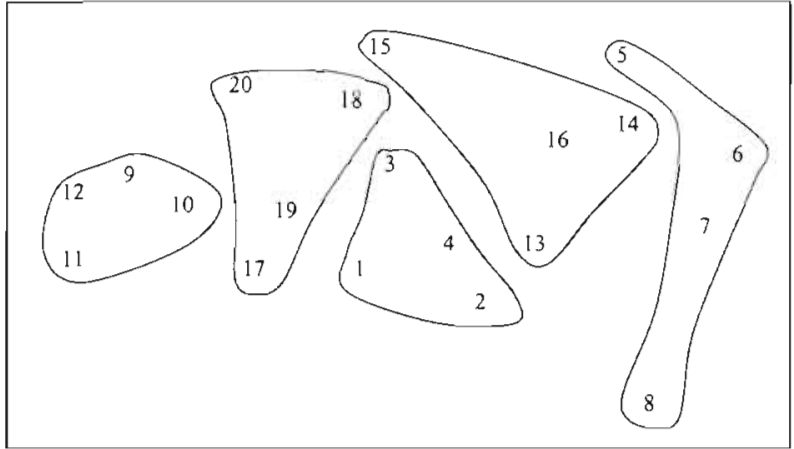

Fig. 2. Multidimensional scaling ordination of young-of-theyear (YOY) decapod community abundance recorded in 5 distinct sub-tidal habitats with varying degrees of physical complexity. Grouping by solid lines indicates replicate samples from each habitat

-0.960 respectively) with rock coverage (Table 6). Dominance showed a significant correlation, $r_{p}=0.984$, to rock coverage. Adult diversity, evenness and dominance were not correlated to site characteristics due to the difficulty in deriving indices for Site 3.

The overall abundance of some individual species showed correlation with site characteristics. Both Cancer pagurus and Necora puber (L.) displayed significant ( $5 \%$ level) correlation $(0.929$ and 0.950 respectively) with algal cover. The hermit crab Anapagurus hyndmanni Thompson showed a strong correlation with rock coverage. Inachus phalangium (Fabricius) abundance was positively correlated with bedrock coverage.

\section{DISCUSSION}

There were clear differences in the structural complexity of most of the sites sampled. The increase in number of species and individuals in habitats with higher rock coverage, although not quite significantly correlated at the $5 \%$ level, concurred with the findings of other studies (Connell \& Jones 1991, Pile et al. 1996, Tupper \& Boutilier 1997, Steele 1999). However, high densities of 1 particular species Pisidia longicornis, led to the very low YOY evenness observed at more com- plex sites. Porcelain crab megalopae are gregarious and settle preferentially in areas inhabited by adults of the species (Jensen 1991). The occurrence of this species in marginal areas containing no adults would suggest that megalopae are sometimes forced to choose sub-optimal habitats, however. The increasing dominance of this species with higher physical complexity resulted in significant negative correlation between rock coverage and both YOY diversity and evenness. This illustrates how high densities of a single species can confuse interpretation if a single univariate measure of diversity is used to describe community diversity.

A clear distinction must be drawn between Sites 3 and 5 . Site 3 offered little shelter to any non-burrowing settler over its entire area, and as a result supported very few adult individuals. Of the 3 adult species encountered, 2 burrow readily into course sand, Xantho pilipes Milne Edwards and Pirimela denticulata (Montagu), while the third, Necora puber, is extremely mobile and ranges over most of the area within the Saltees Sound. No adults of the species Pisidia longicornis were collected. However, Site 5 did afford a certain degree of shelter, in the scattered patches of loose rock overlaying the solid bedrock. Settlement into these patches may have been reduced due to slightly increased tidal currents sweeping over the ridge, but this is speculation as no current velocity data is available for the area. The loose rock patches did, however, support numerous adult species, so it seems likely that immigration occurred some time after settlement. Although the exposed bedrock surfaces were not sampled, and a light settlement into the close turf layer could be envisaged, substantial settlement or subsequent survival of decapod species is unlikely on these patches. Even small variations in physical complexity and site characteristics were observed to lead to significant differences in univariate community statistics. Although algal cover was the only apparent parameter separating Sites 1 and 4 , significant variation in the number of adult species and individuals was observed. The extent of the algal canopy strongly influenced the density of adult individuals between sites. Further increase in variation in habitat characteristics between Sites 1 and 2 led to even further variation in community statistics. 
The higher abundance of certain species, especially the gregarious crab Pisidia longicornis, with increasing habitat complexity contributed to the between-site differences in YOY and adult community structure observed. It is likely that the differences in community structure and the variation in numbers of adult individuals were caused by larval choice and post-settlement mortality and movement, rather than by restrictions or spatial and temporal variations in larval supply. As all sample sites were contained within an area of several hundred $\mathrm{m}^{2}$, it seems reasonable to assume that larval supply was fairly uniform over the entire season. Although small-scale current patterns may have affected settlement, it was assumed that these did not affect settlement strongly between sites. Therefore, the observed differences in YOY community structure between all sites, with the exception of Sites 2 and 4 , would indicate the importance of larval choice and early post-settlement processes in shaping the composition of the YOY community. Post-settlement processes that shape the community, such as predation and migration, appeared to have different relative effects within each of the substrates sampled. The processes acting at Sites 1 and 3 shaped the community composition such that YOY and adult assemblages were significantly different within-site. Recruitment failure of $P$. longicornis and larval avoidance by other species at Site 3 is probably directly related to the lack of shelter afforded to small decapod species that are vulnerable to predation. Small settlers that occupy any of the limited shelter available are likely to quickly outgrow their environment. Migration to a more suitable area that affords shelter becomes necessary when the nursery habitat is unsuitable for the adult organism. Such ontogenetic shifts are commonplace in mobile crustacean species (Cobb \& Wahle 1994, Pile et al. 1996, Moksnes et al. 1998) but are unlikely in a small, shelter-dependant species such as $P$. longicornis. Larger, more mobile species such as Cancer pagurus or Necora puber may be more capable of short migrations from less favourable sites. The influence of post-settlement processes in shaping the community was reflected in between-site differences in adult assemblages. Significant differences in adult community structure were detected across Sites 2 and 4 , which supported similar YOY assemblages. Conversely, similarities in adult structure were observed between sites where YOY structure varied significantly. Of the 3 pairs of sites displaying similarities, 2 involved Sites 1 and 3, locations where YOY and adult assemblages varied within-site. It is likely that YOY species composition is altered before their second year to some degree at all sites, with more dramatic changes occurring at sub-optimal sites where processes have an increased influence on the community.
Although no larval abundance data is available for the study period, inter-annual spatial and temporal variation or restriction in larval supply would be unlikely to influence resultant community structure, especially when considering the small area from which all samples were taken. It would seem likely that the YOY decapod community structures within the habitats studied are strongly mediated by larval choice and early post-settlement processes, although it was not possible to separate their relative influences in this study. The substrate specificity displayed by settling species is variable, and may be linked to reproductive strategy of the species (Palma et al. 1998) or gregarious behaviour (Jensen 1991). Larval choice and/or betweensite variability in post-settlement processes, which may be determined by the nature of the substrate, lead to differences in community structure. The results presented here highlight the need for a detailed knowledge of larval supply processes and dynamics, and post-settlement processes acting on the post-larval population until recruitment and subsequent benthic production has occurred. Understanding of early life history processes is important in defining the shape and scaling of the production-settlement-recruitment model for use in stock prediction. Advances have been made in the development of such recruitment indices and forecasting methods for Australian rock lobster (Phillips \& Brown 1989) Panulirus cygnus George and for the American lobster (Incze \& Wahle 1991) Homarus americanus Milne Edwards. There is excellent potential in the application of suction sampling methods with others, such as settlement tray deployment, to gather detailed and informative data pertaining to the spatial distribution and timing of settlement, and the processes effecting subsequent survival and growth of juvenile decapod species (Robinson \& Tully 1998). However, the detection of significant between-site variation in YOY and adult community structure in this study suggests a need for caution with these pelagic-benthic models. The settler-recruit relationship is obviously affected by habitat complexity and other properties, so the area of each distinct habitat type available and spatial patchiness in larval supply regulate subsequent production and recruitment. Further studies should follow the recommendations of Hughes et al. (1999) in incorporating various spatial scales into the experimental design so that the data obtained accounts for spatial variability in recruitment, such as that revealed in the present study. Variation in physical complexity and other habitat characteristics led to significant differences in YOY community structure across sites. Spatial variability in the magnitude of post-settlement processes acting on YOY communities, including mortality and dispersal, can alter community structure before the end of the second year. This may result in a smoothing of between-site 
inequalities in community structure, reducing spatial variability between more similar sites over time and allowing generalised categories of recruitment habitats to be defined.

Acknowledgements. M.R. was funded by the IRAM scholars program, BIM Dublin and a scholarship award from Trinity College Dublin.

\section{LITERATURE CITED}

Boudreau B, Bourget E, Simard Y (1993) Effects of age, injury, and predator odours on settlement and shelter selection by lobster Homarus americanus postlarvae. Mar Ecol Prog Ser 93:119-129

Clarke KR, Warwick RM (1994) Change in marine communities: an approach to statistical analysis and interpretation. Bourne Press Limited, Bournemouth

Cobb JS, Wahle RA (1994) Early life history and recruitment processes of clawed lobsters. Crustaceana 67:1-25

Cobb JS, Gulbransen BF, Phillips BF, Wang D, Sysio M (1983) Behaviour and distribution of larval and early juvenile Homarus americanus. Can J Fish Aquat Sci 40:2184-2188

Cobb JS, Booth JD, Clancy M (1997) Recruitment strategies in lobsters and crabs: a comparison. Mar Freshw Res 48: $797-806$

Connell S.D, Jones GP (1991) The influence of habitat complexity on post-recruitment processes in a temperate reef fish population. J Exp Mar Biol Ecol 151:271-294

Crisp DJ, Meadows PS (1962) The chemical basis of gregariousness in cirripedes. Proc R Soc Lon 156:500-520

Diaz H, Orihuela B, Forward RB Jr, Rittschof D (1999) Orientation of the blue crab, Callinectes sapidus (Rathbun), megalopae: responses to visual and chemical cues. $J$ Exp Mar Biol Ecol 233:25-40

Doherty PJ (1994) An empirical test of recruitment limitation in coral reef fish. Science 263:935-939

Forward RB Jr, DeVries MC. Rittschof D, Frankel DAZ, Bischoff JP, Fisher CM, Welch JM (1996) Effects of environmental cues on metamorphosis of the blue crab Callinectes sapidus. Mar Ecol Prog Ser 131:165-177

Gosselin LA, Qian PY (1997) Juvenile mortality in benthic marine invertebrates. Mar Ecol Prog Ser 146:265-282

Hughes TP, Baird AH, Dinsdale EA, Moltschaniwskyj NA, Pratchett MS, Tanner JE, Willis BL (1999) Patterns of recruitment and abundance of corals along the Great Barrier Reef. Nature 397:59-63

Incze LS, Wahle RA (1991) Recruitment from pelagic to early benthic phase in lobsters Homarus americanus. Mar Ecol Prog Ser 79:77-87

Incze LS, Wahle RA, Cobb JS (1997) Quantitative relationships between postlarval production and benthic recruitment in lobsters, Homarus americanus. Mar Freshw Res 48:729-743

Iribarne O, Fernandez M, Armstrong D (1994) Does space competition regulate density of juvenile Dungeness crab Cancer magister Dana in sheltered habitats? J Exp Mar Biol Ecol 183:259-271

Jensen GC (1991) Competency, settling behaviour, and postsettlement aggregation by porcelain crab megalopae (Anomura: Porcellanidae). J Exp Mar Biol Ecol 153:49-61

Keough MJ, Downes BJ (1982) Recruitment of marine invertebrates: the role of active larval choices and early mortality. Oecologia 54:348-352

Kruskal JB, Wish M (1978) Multidimensional scaling. Sage
Publications, Beverly Hills

McConnaughey RA, Armstrong DA, Hickey BM, Gunderson DR (1992) Juvenile Dungeness crab (Cancer magister) recruitment variability and oceanic transport during the pelagic larval phase. Can J Fish Aquat Sci 49:2028-2044

Moksnes PO (1999) Recruitment regulation in juvenile shore crabs Carcinus maenas: importance of intraspecific interactions in space limited refuge habitats. PhD thesis, Göteborg University

Moksnes PO, Pihl J, van Montfrans J (1998) Predation on postlarvae and juveniles of the shore crab Carcinus maenas: importance of shelter, size and cannibalism. Mar Ecol Prog Ser 166:211-225

Morgan SG, Zimmer-Faust RK, Heck KL, Coen LD (1996) Population regulation of blue crabs Callinectes sapidus in the northern Gulf of Mexico: postlarval supply. Mar Ecol Prog Ser 133:73-88

Palma AT, Wahle RA, Steneck RS (1998) Different early postsettlement strategies between American lobsters Homarus americanus and rock crabs Cancer irroratus in the Gulf of Maine. Mar Ecol Prog Ser 162:215-225

Perkins-Visser E, Wolcott TG, Wolcott DL (1996) Nursery role of seagrass beds: enhanced growth of juvenile blue crabs (Callinectes sapidus Rathbun). J Exp Mar Biol Ecol 198: $155-173$

Phillips BF, Brown RS (1989) The West Australian rock lobster fishery: research for management. In: Caddy JF (ed) Marine invertebrate fisheries: their assessment and management. John Wiley \& Sons, Chichester, p 159-181

Pile AJ, Lipcius RN, van Montfrans J, Orth RJ (1996) Densitydependant settler-recruit-juvenile relationships in blue crabs. Ecol Monogr 66:277-300

Risk A (1997) Effects of habitat on the settlement and post-settlement success of the ocean surgeonfish Acanthurus bahianus. Mar Ecol Prog Ser 161:51-59

Robinson M, Tully $O$ (1998) Settlement and growth of early benthic phase Cancer pagurus. ICES CM 1998/G:10

Roughgarden J, Gaines S, Possingham H (1988) Recruitment dynamics in complex life cycles. Science 241:1460-1466

Steele MA (1999) Effects of shelter and predators on reef fishes. J Exp Mar Biol Ecol 233:65-79

Stevens BG, Kittaka J (1998) Postlarval settling behaviour, substrate preference, and time to metamorphosis for red king crab Paralithodes camtschaticus. Mar Ecol Prog Ser 167:197-206

Tupper M, Boutilier RG (1997) Effects of habitat on settlement, growth, predation risk and survival of a temperate reef fish. Mar Ecol Prog Ser 151:225-236

Wahle RA (1992) Substratum constraints on body size and the behavioural scope of shelter use in the American lobster. J Exp Mar Biol Ecol 159:59-75

Warwick RM, Clarke KR, Gee JM (1990) The effects of disturbance by soldier crabs Mictyris platycheles $\mathrm{H}$ Milne Edwards on meiobenthic community structure. J Exp Mar Biol Ecol 135:19-33

Welch JM, Rittschof D, Bullock TM, Forward RB Jr (1998) Effects of chemical cues on settlement behaviour of blue crab Callinectes sapidus postlarvae. Mar Ecol Prog Ser $154: 143-153$

White RG, Hill AE, Jones DA (1988) Distribution of Nephrops norvegicus (L.) larvae in the western Irish Sea: an example of advective control on recruitment. J Plankton Res 10 : $735-747$

Young EF, Bigg GR, Grant A, Walker P, Brown J (1998) A modelling study of environmental influences on bivalve settlement in The Wash, England. Mar Ecol Prog Ser 172: $197-214$ 